\title{
Analysis of Students' Internet Utilization to Improve Public Information Literacy in the Industrial Revolution Era 4.0
}

\author{
Sri Nurhayati ${ }^{1, *}$ (D) and Safuri Musa ${ }^{2}$
}

${ }^{1}$ Department of Community Education, Faculty of Science Education, Institut Keguruan dan Ilmu Pendidikan Siliwangi, 40526, Cimahi, West Java, Indonesia

2 Department of Non-Formal Education, Faculty of Teacher Training and Education, Universitas Singaperbangsa Karawang, 41361, Karawang, West Java, Indonesia

* Corresponding Author: srinurhayati@ikipsiliwangi.ac.id

\section{ARTICLE INFO}

Publication Info:

Research Article

How to cite:

Nurhayati, S., E Musa, S. (2020).

Analysis of Students' Internet

Utilization to Improve Public

Information Literacy in the

Industrial Revolution Era 4.0.

Society, 8(2), 557-566.

DOI: $10.33019 /$ society.v8i2.231

Copyright (C) 2020. Owned by Author(s), published by Society

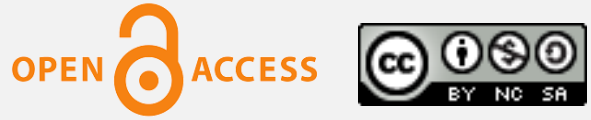

This is an open-access article.

License: Attribution-

NonCommercial-ShareAlike (CC BY-NC-SA)

\section{ABSTRACT}

This research aims to determine the level of information literacy, internet utilization as a source of information literacy, and internet utilization to increase student reading interest at Institut Keguruan dan Ilmu Pengetahuan Siliwangi (IKIP Siliwangi). This research uses qualitatif descriptive method. Data were collected using questionnaires, interviews, and documentation studies. Selection of research subjects using the snowball sampling technique. This research's subjects consisted of 23 students related to literacy, 16 students related to information literacy, 18 students related to the results of internet utilization in increasing students' reading interest, and 1 lecturer of Community Education at IKIP Siliwangi. The results showed that students 'understanding of information seeking and information selection was still low compared to students' understanding of information dissemination. Students are still not optimal in using information literacy. Only a few students understand information literacy, how to use information literacy, and select information. Students understand the use of the internet and use it only for social media activities, but low in utilizing the internet as a learning source. Also, the results of the study indicated that students' reading interest was low. Students choose to use the internet instead of reading books. Students do not feel the need to come to the library to find books that match what they need to learn. Therefore, students have to understand the concept of information literacy and take advantage of various applications that support learning. 
Received: September 2, 2020;

Accepted: December 22, 2020;

Published: December 28, 2020;

\section{Keywords: Information Literacy; Internet Utilization; Learning Source; Reading Interest; Social Media; Student Understanding}

\section{Introduction}

The era of the Industrial Revolution 4.0 made technology the basis for various aspects of human life (Kementerian Riset, Teknologi dan Pendidikan Tinggi Republik Indonesia, 2018). This era can be used as a trigger for the Indonesian state to prepare competent, competitive, and highly competitive human resources during competition and the rapid development of global information technology. To face the Industrial Revolution 4.0, the government launched a three literacy movement: digital, technology, and people (Aoun, 2018). This literacy movement is a needed skill in a future that uses the internet a lot. The research results on internet utilization showed that $57 \%$ of internet utilization is related to communication and $43 \%$ involves web browsing (Nie et al., 2005).

The current development of the internet has made digital skills fundamental. Digital skills are a determining factor for an individual's ability to use the internet, and inseparable from technological literacy skills, namely individuals' ability to adopt, adapt, discover, and evaluate technology to positively affect life, communities, and their environment (Hansen, 2003).

Technological literacy skills are a form of literacy today and are as important as reading and writing skills in the previous decade (Rivoltella, 2008). Someone who has these skills will know how to learn because they understand how to manage information, evaluate, sort, and use it according to applied ethics. However, in Indonesia, public information literacy skills are still low and are also due to the low interest in reading (Wahyuni, 2009; Rachmawati et al., 2018; Ghasya et al., 2018). Information literacy can identify information needed, understand information organizations, identify appropriate sources of information, search for core sources, evaluate sources critically, and disseminate information following applicable norms (Odede \& Nsibirwa, 2018).

The research aims to determine the level of information literacy, the use of the internet as a source of information literacy, and motivation to increase students' reading interest at IKIP Siliwangi.

\section{Literature Review}

\subsection{Industrial Revolution 4.0}

Industrial Revolution 4.0 arose from a German project to promote computerized manufacturing and aimed to transform the manufacturing industry with digital processes and exploit the potential of new technologies (Rojko, 2017). Löffler \& Tschiesner (2013) explained that the 4.0 Industrial Revolution principles are merging machines, processes, and work systems by implementing intelligent networks to control and relate to one another independently. According to Umachandran et al. (2019), Industrial Revolution 4.0 has a system with transformative technology to manage systems interrelated between physical resources and computing capabilities.

The Industrial Revolution 4.0 characterized by the digitization of manufacturing triggered by 1) an increase in the amount of data, computing power, and connectivity; 2) the emergence of business analysis, skills, and intelligence; 3) forming new interactions between humans and machines; 4) improving digital transfer instructions to the physical world, such as robotics and 3D printing (Lee et al., 2013). 
One of the Industrial Revolution 4.0's unique features is the application of Artificial Intelligence (AI) (Tjandrawinata, 2016). For example, robots can replace humans' roles to be cheaper, more effective, and efficient. Baur \& Wee (2015) have mapped the Industrial Revolution 4.0 with the term digital compass, as follows:

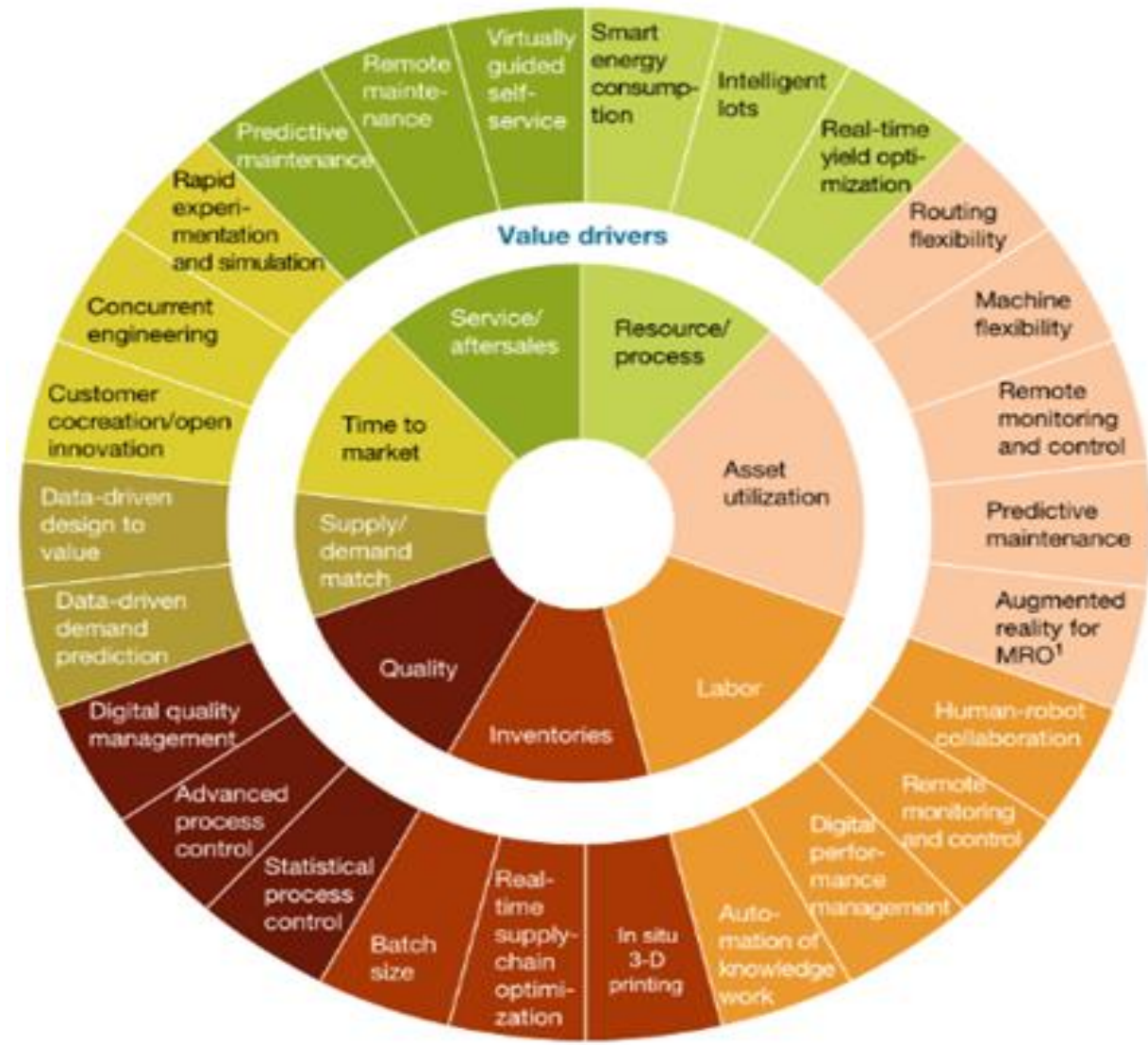

Figure 1. Industrial Revolution 4.0 Level

Source: Baur \& Wee (2015)

\subsection{Information Literacy Definition}

Information literacy is an essential skill in searching for knowledge, including awareness of information needed and can find efficiently, evaluated, used effectively, and communicated clearly in the environment (Ati, 2015). According to UNESCO as cited in Lien (2010), information literacy is a person's skills in needs awareness of information, and when information is needed. It also identifies and locates the required information, critically evaluates information, organizes and integrates information into existing knowledge, and utilizes and communicates it effectively, legally, and ethically (University of Idaho, 2011; Rachmawati et al., 2017). Due to current technological developments, information literacy has become necessary in the use of electronic information sources. Electronic information resources' complexity requires a person to have information literacy skills (Odede \& Nsibirwa, 2018). According to Adeleke \& Emeahara (2016), information literacy skills are essential to access information in advancing technology in this generation. Most of the information required by almost all research is from electronic sources.

Based on the above definition, information literacy is a person's ability or skill to find the information needed and communicate to looking for learning materials or learning resources. According to Neely (2006), higher education literacy includes five standard components and 22 performance indicators, as follows: 
Analysis of Students' Internet Utilization to Improve Public Information Literacy in the Industrial Revolution Era 4.0

Table 1. Information Literacy Indicators in Higher Education

\begin{tabular}{|c|c|c|}
\hline Standards & Objectives & Performance Indicators \\
\hline 1 & $\begin{array}{l}\text { Determining Information } \\
\text { Needs. }\end{array}$ & $\begin{array}{l}\text { 1. Using the idea of the information needed. } \\
\text { 2. Identify the types of potential sources of } \\
\text { information. } \\
\text { 3. Consider the benefits and value of the } \\
\text { information received. } \\
\text { 4. Evaluating the level of need and information } \\
\text { characteristics. }\end{array}$ \\
\hline 2 & $\begin{array}{l}\text { Access the required } \\
\text { information effectively and } \\
\text { efficiently. }\end{array}$ & $\begin{array}{l}\text { 1. Select a suitable information retrieval system } \\
\text { to access information. } \\
\text { 2. Develop and work on an effective } \\
\text { information retrieval strategy design. } \\
\text { 3. Rediscover information either manually or } \\
\text { online by the various methods used. } \\
\text { 4. Selecting information-seeking strategies if } \\
\text { needed. } \\
\text { 5. Select, store, and process information and its } \\
\text { sources. }\end{array}$ \\
\hline 3 & $\begin{array}{l}\text { 1. Perform critical evaluation } \\
\text { of information and its } \\
\text { sources. } \\
\text { 2. Combining selected } \\
\text { information with } \\
\text { previously acquired } \\
\text { knowledge. }\end{array}$ & $\begin{array}{l}\text { 1. Summarize the primary information from the } \\
\text { information collected. } \\
\text { 2. Use criteria to evaluate information and its } \\
\text { sources } \\
\text { 3. Combining main ideas to create a new } \\
\text { concept. } \\
\text { 4. Comparing new knowledge with previous } \\
\text { ones to determine the value of contention, } \\
\text { additions, and other information } \\
\text { characteristics. } \\
\text { 5. Determine the effect of new knowledge on } \\
\text { individual worth and take steps to deal with } \\
\text { differences. } \\
\text { 6. Agree on the understanding and } \\
\text { interpretation of experts or others about } \\
\text { information by way of discussion. } \\
\text { 7. Determine whether the original question can } \\
\text { be corrected. }\end{array}$ \\
\hline 4 & $\begin{array}{l}\text { Use information effectively to } \\
\text { accomplish specific goals. }\end{array}$ & $\begin{array}{l}\text { 1. Using previous information and new } \\
\text { information to plan and create research } \\
\text { performance or results. } \\
\text { 2. Improve the development process for results } \\
\text { or performance. } \\
\text { 3. Deliver performance or results to others } \\
\text { effectively. }\end{array}$ \\
\hline
\end{tabular}

Copyright $\odot$ 2020. Owned by Author(s), published by Society. This is an open-access article under the CC-BY-NC-SA license. 


\begin{tabular}{lll}
\hline Standards & \multicolumn{1}{c}{ Objectives } & \multicolumn{1}{c}{ Performance Indicators } \\
\hline 5 & $\begin{array}{l}\text { Understand the economic, } \\
\text { legal, and social aspects } \\
\text { related to the use and access } \\
\text { of information legally and } \\
\text { ethically }\end{array}$ & $\begin{array}{l}\text { 1. } \begin{array}{l}\text { Understand various socio-economic, legal, } \\
\text { and ethical aspects, which cover information } \\
\text { and information technology. }\end{array} \\
\end{array}$ \\
& $\begin{array}{l}\text { 2. Follow institutional, regulatory, legal, and } \\
\text { ethical policies related to access and use of } \\
\text { information. } \\
\text { Declare the use of information and sources of } \\
\text { information in delivering performance or } \\
\text { results. }\end{array}$ \\
\hline
\end{tabular}

\subsection{Internet Definition}

Internet is a means that can connect one person to another to communicate, receive, and disseminate information. According to Aminy (2015), the internet is a technology that can create a rich and flexible learning atmosphere and can support and fulfill education and training to make changes and developments quickly.

\section{Research Methodology}

This research uses a qualitative descriptive method to determine internet utilization as a source of information literacy on students' reading interest. According to Sugiyono (2008), qualitative descriptive research is a research method that has a philosophical basis for postpositivism to examine objective natural conditions in which the researcher acts as the key instrument. Meanwhile, Nawawi \& Martini (1994) explained that the descriptive method describes objectives or events based on real facts and draws conclusions based on these historical facts.

This research conduct at IKIP Siliwangi campus. Subjects were selected purposively uses a snowball sampling technique. This research's subjects consisted of 23 students related to literacy, 16 students related to information literacy, 18 students related to the results of internet utilization in increasing students' reading interest, and 1 lecturer of Community Education at IKIP Siliwangi.

The stages taken during the research were as follows:

1) Preparation Stage

Prepare appropriate methods to assess levels of information literacy, internet utilization, and reading interest.

2) Implementation Stage

Questionnaires were made and distributed to students. Conduct reading interest reviews and student interviews in person.

3) Evaluation Stage

Drawn conclusions and solutions as evaluation substances in order to obtain better results in the future.

\section{Results and Discussion}

\subsection{Levels of Student Information Literacy}

Based on the questionnaire results, there was an increase in information literacy in the Community Education Study Program, IKIP Siliwangi, as follows: 


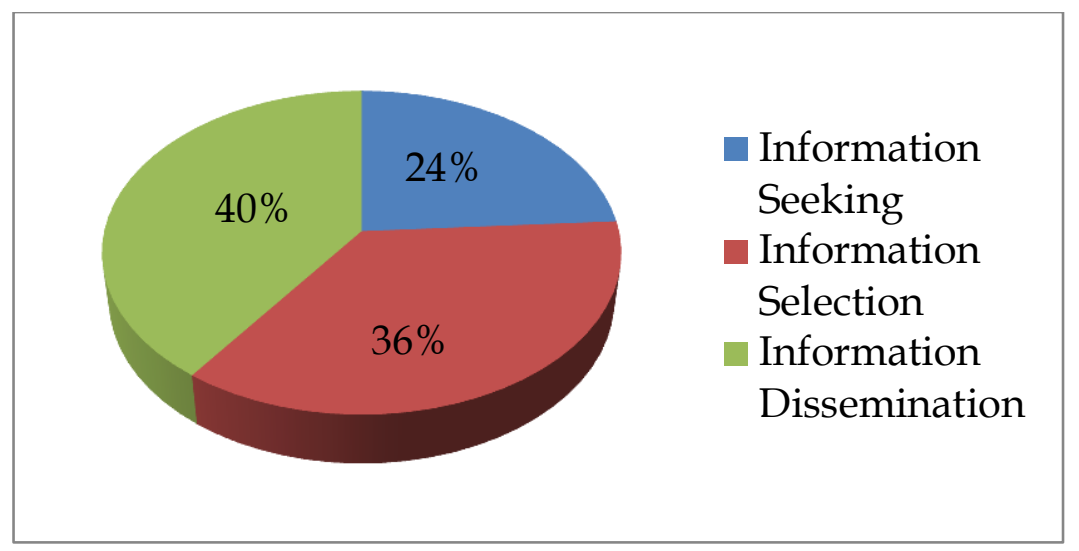

Figure 2. Information Literacy Levels

Source: Primary Data (2020)

Students' understanding of information seeking and information selection was still low compared to students' understanding of information dissemination. Students are still not optimal in using information literacy, and there are still many who do not understand information literacy, how to use information literacy, and selecting information. Therefore, students need guidance and direction to be able to use the information correctly and appropriately.

Information literacy skills are related to the ability and competence to identify when information is needed, evaluate, and use it to make decisions (Ukachi, 2015). The primary key in understanding information literacy is understanding related to the use of information literacy. Shao \& Purpur (2016) states that information literacy is a thinking skill needed to develop and support academic, professional, and personal success. Training information literacy in learning and independently developing research skills are necessary for marketing professionals (Schroeter \& Higgins, 2015).

\subsection{Internet Utilization as a Source of Student Information Literacy}

Corral (1998) emphasizes two crucial components in information literacy: 1) IT skills, necessary skills in operating computers, and 2) information handling skills, including information sources, evaluation criteria, navigation methods, manipulation techniques, and presentation. A person with information literacy skills can explore the vast and complex information, whether in printed or electronic media (Hasugian, 2008).

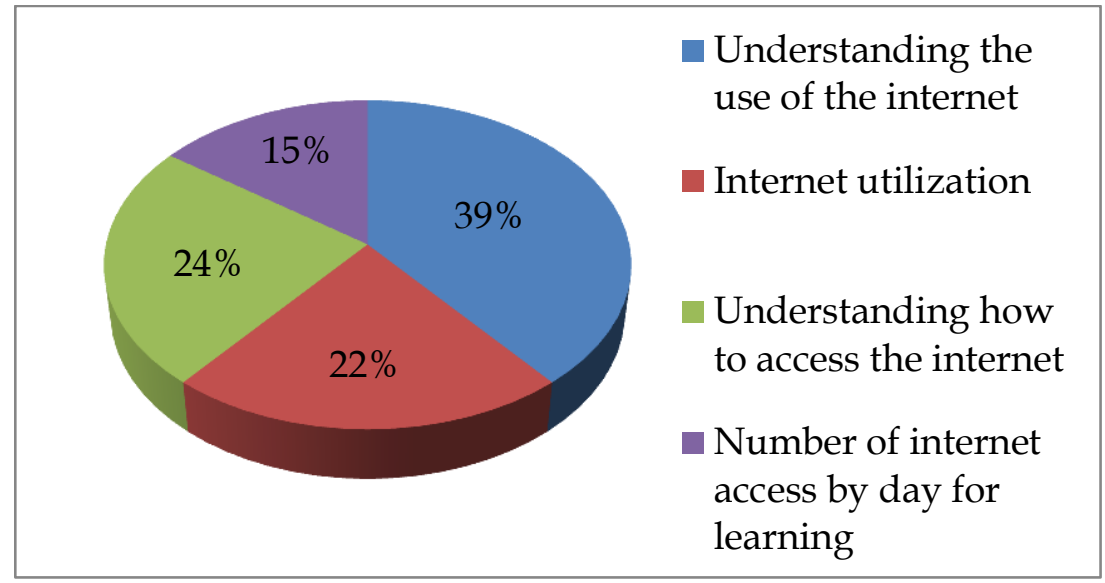

Figure 3. Internet Utilization as Information Literacy

Source: Primary Data (2020)

Copyright (C) 2020. Owned by Author(s), published by Society. This is an open-access article under the CC-BY-NC-SA license. 
Figure 3 shows the results of using the internet as information literacy in the Community Education Study Program, IKIP Siliwangi, which was obtained based on the questionnaire results. Students understand the use of the internet but are low in utilizing the internet as a learning resource. Students still use the internet to access social media, but some use the internet for learning purposes, access information provided, and research. The low level of internet utilization in learning can affect students' improvement, development, and knowledge. Therefore, hopefully, every lecture taught must include information literacy indicators.

\subsection{Internet Utilization to Increase Reading Interest}

Students' low reading interest is due to technology development, more attractive entertainment venues, and less attractive libraries.

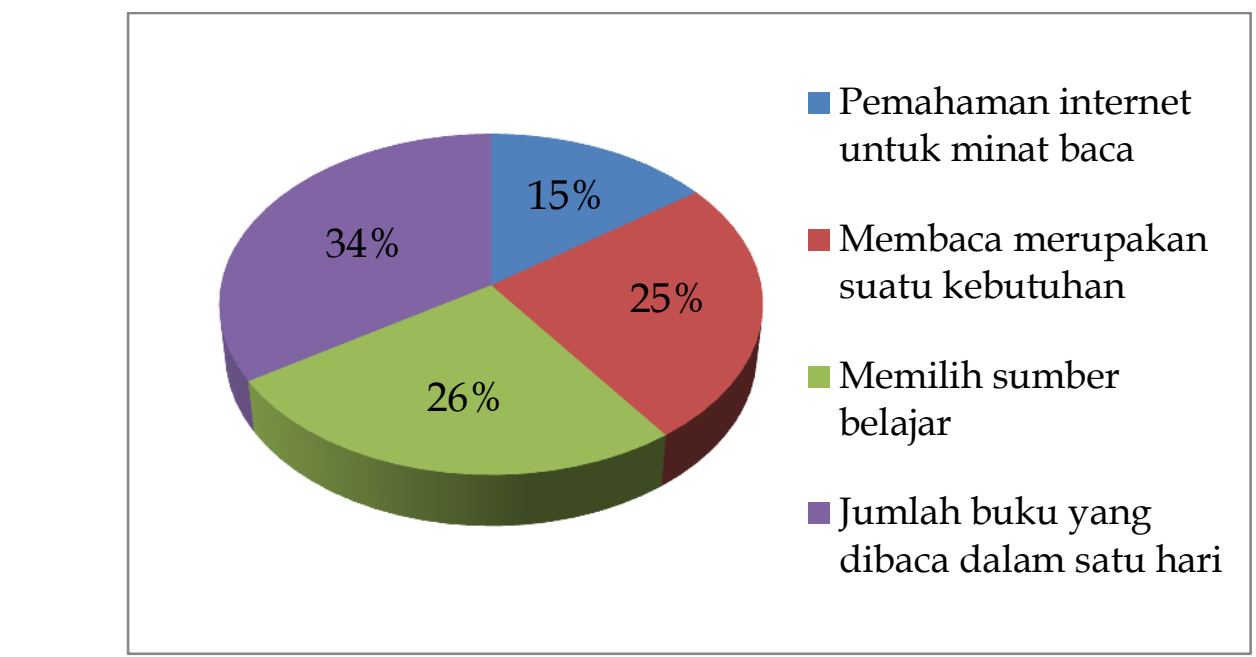

Figure 4. The Result of Internet Utilization to Increase Reading Interest Source: Primary Data (2020)

Figure 4 shows the results of internet utilization to increase student reading interest in the Community Education Study Program, IKIP Siliwangi, which was obtained based on the questionnaire results. The results showed that the students' low interest in reading was due to students preferring to use the internet with its various features rather than going to the library to read books. Therefore, students can read various books, magazines, news, and others on the internet as learning sources.

Besides, other factors that cause the low reading interest of IKIP Siliwangi students are the high price of new books and limited library facilities. However, even though the university has provided internet access facilities, students still use it for social media rather than access learning resources.

Internet utilization can increase student interest in learning because of the influence of innovation in the teaching and learning process carried out by teachers in schools (Situmorang, 2012). A person can search for various things through the internet, from subjects to general science (Syafrudin \& Utomo, 2009). Internet utilization, as a source of education, has been widely used among students. Besides books, the internet as a learning tool aims to overcome students' low interest in reading and learning.

According to UNESCO, Indonesia's reading interest index is only around 0.001 , categorized as very low. It means one person who is interested in reading in a thousand Indonesian people. Many factors cause someone to be lazy to read, including culture (environment), technological 
advances and printed reading sources completeness (Republika Online, 2016). Advances in technology also cause someone to need something instant to understand something. It makes gadgets are more attractive than books.

\section{Conclusion}

The research results concluded that students' understanding of information seeking and information selection was still low compared to students' understanding of information dissemination. Students are still not optimal in using information literacy. Many students do not understand information literacy, how to use information literacy, and selecting information.

In general, students understand the use of the internet but are low in using the internet as a learning resource. Students still use the internet for social media. However, students who access the internet for learning purposes, access the information provided, and research are very few. The internet, which is very easy to access and use, makes students less interested in visiting the library to find the literature they need. Thus, students are encouraged to understand the information literacy concept and understand and take advantage of various applications that support learning.

\section{Acknowledgment}

The authors are grateful to express gratitude to all of those who have had the pleasure to work during this research conducted.

\section{Declaration of Conflicting Interests}

The authors have declared no potential conflicts of interest concerning the research, authorship, and/or publication of this article.

\section{References}

Adeleke, D. S., \& Emeahara, E. N. (2016). Relationship between information literacy and use of electronic information resources by postgraduate students of the University of Ibadan. Library Philosophy and Practice (E-Journal), 1381. Retrieved from http:/ / digitalcommons.unl.edu/libphilprac/1381

Aminy, S. Y. (2015). Implementasi Pendidikan Umum di Universitas Pendidikan Indonesia (Master's dissertation). Universitas Pendidikan Indonesia. Retrieved from http://repository.upi.edu/18035/

Aoun, J. E. (2018). Robot-Proof: Higher Education in the Age of Artificial Intelligence (The MIT Press). Cambridge, Massachusetts: The MIT Press.

Ati, S. (2015). Analisis Literasi Informasi Pemakai Taman Bacaan Masyarakat. Jurnal Kajian Informasi Dan Perpustakaan, 3(1), 89-100. https:// doi.org/10.24198/jkip.v3i1.9492

Baur, C., \& Wee, D. (2015). Manufacturing's next act. Retrieved from https://www.mckinsey.com/business-functions/operations/ourinsights/manufacturings\%20next-act\#

Corrall, S. (1998). Key skills for students in higher education. SCONUL Newsletter,15, 25-29.

Ghasya, D. A. V., Johan, G. M., \& Kasmini, L. (2018). Peningkatan Kemampuan Literasi Informasi Berdasarkan Standar ACRL melalui Pemanfaatan Multimedia bagi Guru Sekolah Dasar. Visipena Journal, 9(2), 374-384. https://doi.org/10.46244/visipena.v9i2.466 
Hansen, J. W. (2003). To Change Perceptions of Technology Programs. The Journal of Technology Studies, 29(2), 16-19. https:/ / doi.org/10.21061/jots.v29i2.a.10

Hasugian, J. (2008). Urgensi literasi informasi dalam kurikulum berbasis kompetensi di perguruan tinggi. Pustaha, 4(2), 34-44. Retrieved from http://jurnalindustri.petra.ac.id/index.php/pus/article/view/17231

Kementerian Riset, Teknologi dan Pendidikan Tinggi Republik Indonesia. (2018, January 17). Pengembangan Iptek dan Pendidikan Tinggi di Era Revolusi Industri 4.0. Retrieved from https:/ / www.ristekbrin.go.id/ pengembangan-iptek-dan-pendidikan-tinggi-di-erarevolusi-industri-4-0-2/

Lee, J., Lapira, E., Bagheri, B., \& Kao, H.-. (2013). Recent advances and trends in predictive manufacturing systems in big data environment. Manufacturing Letters, 1(1), 38-41. https:/ / doi.org/10.1016/j.mfglet.2013.09.005

Lien, D. A. (2010). 7 Langkah Knowledge Management. Jakarta, Indonesia: Universitas Atmajaya.

Löffler, M., \& Tschiesner, A. (2013). The Internet of Things and the future of manufacturing. Retrieved from https://www.mckinsey.com/business-functions/mckinsey-digital/ourinsights/the-internet-of-things-and-the-future-of-manufacturing\#

Nawawi, H., \& Martini, M. (1994). Penelitian Terapan. Yogyakarta, Indonesia: Gajahmada University Press.

Neely, T. Y. (2006). Information Literacy Assessment: Standards-Based Tools and Assignments. Chicago, Illinois: American Library Association.

Nie, N. H., Simpser, A., Stepanikova, I., \& Zheng, L. (2005). Ten years after the birth of the Internet, how do Americans use the Internet in their daily lives? Retrieved from http://www.stanford.edu/group/siqss/

Odede, I. R., \& Nsibirwa, Z. (2018). Information literacy skills in using electronic information resources. Library Philosophy and Practice (e-journal), 1947. Retrieved from https://digitalcommons.unl.edu/libphilprac/1947/

Rachmawati, T. S., Fitriawati, F., \& Saepudin, E. (2017). Studi tentang Kemampuan Literasi Informasi di Kalangan Siswa Menengah Pertama. Edulib, 7(2), 17-28. https://doi.org/10.17509/edulib.v7i2.9488

Rachmawati, T. S., Winoto, Y., \& Rohman, A. S. (2018). Studi tentang Pemetaan Budaya Literasi Informasi pada Masyarakat Pesisir Selatan Jawa Barat. Record and Library Journal, 4(1),1-6. http:/ / dx.doi.org/10.20473/rlj.V4-I1.2018.1-7

Republika Online. (2016, April 29). Di Indonesia, Hanya 1 dari 1.000 Orang yang Serius Membaca Buku. Retrieved from https:/ / republika.co.id/berita/pendidikan/eduaction/16/04/29/o6dpyg335-diindonesia-hanya-1-dari-1000-orang-yang-serius-membaca-buku

Rivoltella, P. C. (2008). Digital Literacy: Tools and Methodologies for Information Society (1st ed.). Hershey, Pennsylvania: IGI Publishing.

Rojko, A. (2017). Industry 4.0 concept: background and overview. International Journal of Interactive Mobile Technologies (iJIM), 11(5), 77-90. Retrieved from https:// onlinejour.journals.publicknowledgeproject.org/index.php/ijim/article/view/7072

Schroeter, C., \& Higgins, L.M. (2015). The impact of guided vs. self-directed instruction on students' information literacy skills. Journal for Advancement of Marketing Education, 23(1), 1-10. http://www.mmaglobal.org/publications/JAME/JAME-Issues/JAME-2015Vol23-Issue1/JAME-2015-Vol23-Issue1-Schroeter-Higgins-pp1-11.pdf 
Shao, X., \& Purpur, G. (2016). Effects of Information Literacy Skills on Student Writing and Course Performance. The Journal of Academic Librarianship, 42(6), 670-678. https://doi.org/10.1016/j.acalib.2016.08.006

Situmorang, P. L. (2012). Pengaruh Penggunaan Media Internet terhadap Prestasi Belajar Ekonomi Siswa Kelas XI IPS SMA Swasta Bersama Berastagi Tahun Ajaran 2011/2012 (Undergraduate Thesis). Universitas Negeri Medan. Retrieved from http://digilib.unimed.ac.id/13183/

Sugiyono. (2008). Metode Penelitian Kuantitatif Kualitatif dan RED. Bandung, Indonesia: ALFABETA.

Syafrudin., \& Utomo, E. P. (2009). Pengertian Teknologi Internet. Bandung, Indonesia: Informatika.

Tjandrawinata, R. R. (2016). Industri 4.0: Revolusi industri abad ini dan pengaruhnya pada bidang kesehatan dan bioteknologi. Jurnal Medicinus, 29(1), 31-39.

Umachandran, K., Jurčić, I., Della Corte, V., \& Ferdinand-James, D. S. (2019). Industry 4.0: The New Industrial Revolution. In Dey, N., \& Tamane, S. (Ed.), Big Data Analytics for Smart and Connected Cities (pp. 138-156). IGI Global. http://doi:10.4018/978-1-5225-62078.ch006

Ukachi, N. B. (2015). Exploration of information literacy skills status and impacts on the quality of life of artisans in Lagos, Nigeria. New Library World, 116(9/10), 578-587. https://doi.org/10.1108/nlw-01-2015-0006

University of Idaho. (2011). Information literacy. Retrieved from https://www.webpages.uidaho.edu/info_literacy/

Wahyuni, S. (2009). Menumbuhkembangkan Minat Baca Menuju Masyarakat Literat. Diksi, 16(2), 179-189. https:// doi.org/10.21831/diksi.v16i2.6617

\section{About the Authors}

1. Sri Nuryahati, obtained her Doctoral degree in Community Education from Universitas Pendidikan Indonesia, in 2018. The author is an Assistant Professor at the Department of Community Education, Faculty of Science Education, Institut Keguruan dan Ilmu Pendidikan Siliwangi, Indonesia.

E-Mail: srinurhayati@ikipsiliwangi.ac.id

2. Safuri Musa, obtained his Doctoral degree from Universitas Pendidikan Indonesia, in 2003. The author is an Assistant Professor at the Department of Non-Formal Education, Faculty of Teacher Training and Education, Universitas Singaperbangsa Karawang, Indonesia.

E-Mail: safuri@unsika.ac.id 